\title{
Concentrations of Silver Nitrate in the In Vitro Development and Conservation of Passiflora gibertii N. E. Brown
}

\author{
Gláucia Amorim Faria ${ }^{1 *}$, Lucas Menezes Felizardo², Antonio Flávio Arruda Ferreira1, \\ Paula Suares Rocha ${ }^{3}$, Aline Namie Suzuki ${ }^{1}$, Antônio da Silva Souza4, Tatiana Góes Junghans ${ }^{4}$, \\ Maria Angélica Pereira de Carvalho Costa ${ }^{5}$, Ana Patricia Bastos Peixoto ${ }^{6}$, \\ Augusto Ramalho de Morais ${ }^{7}$, Beatriz Garcia Lopes ${ }^{1}$, Tiago Almeida de Oliveira ${ }^{6}$
}

\footnotetext{
${ }^{1}$ Departmentof Mathematics, School of Engineering, São Paulo State University (Unesp), Ilha Solteira, Brazil

${ }^{4}$ Embrapa Cassava and Fruticulture, Cruz das Almas, Brazil Almas, Brazil

${ }^{6}$ Department of Statistics, State University of Paraíba (UEPB), Campina Grande, Brazil

${ }^{7}$ Department of Exact Sciences, Federal University of Lavras (UFLA), Lavras, Brazil

Email:^glaucia@mat.feis.unesp.br
}

${ }^{2}$ Department of Civil Engineering, School of Engineering, São Paulo State University (Unesp), Ilha Solteira, Brazil

${ }^{3}$ Laboratory of Environmental Mutagenesis, Institute of Biosciences, São Paulo State University (Unesp), Rio Claro, Brazil

${ }^{5}$ Center for Agrarian, Biological and Environmental Sciences, Federal University of the Recôncavo of Bahia (UFRB), Cruz das

How to cite this paper: Faria, G.A., Felizardo, L.M., Ferreira, A.F.A., Rocha, P.S., Suzuki, A.N., Souza, A.S., Junghans, T.G., Costa, M.A.P.C., Peixoto, A.P.B., Morais, A.R., Lopes, B.G. and Oliveira, T.A. (2017) Concentrations of Silver Nitrate in the In Vitro Development and Conservation of Passiflora gibertii N. E. Brown. American Journal of Plant Sciences, 8, 2944-2955. https://doi.org/10.4236/ajps.2017.812199

Received: September 14, 2017

Accepted: November 7, 2017

Published: November 13, 2017

Copyright (c) 2017 by authors and Scientific Research Publishing Inc. This work is licensed under the Creative Commons Attribution International License (CC BY 4.0).

http://creativecommons.org/licenses/by/4.0/

cc) (i) Open Access

\begin{abstract}
The aim of this study was to evaluate the effects of silver nitrate in the in vitro development and conservation of passion fruit plants. Experiments were carried out at the Laboratory of Culture and Tissues, in the National Cassava and Fruits Research Center (EMBRAPA), using microcuttings of Passiflora gibertii N. E. Br., previously cultivated in vitro. The microcuttings were placed in MS media supplemented with silver nitrate at concentrations of $0,1,2,4$ and 8 $\mathrm{mg} \cdot \mathrm{L}^{-1}$, and, during 30, 60 and 90 days, the following variables were identified: Shooting length $(\mathrm{cm})$, number of roots, number and coloration of leaves. A completely randomized design with 30 replications in a split-plot scheme was employed. Polynomial regression equations were adjusted in analysis of variance to compare averages of treatments. The obtained results support the assumption of high sensitivity of passion fruit tissues to ethylene, which reflects in the lost of vigor and in the induction of culture senescence by its accumulation. Based on obtained results, and in order to mitigate this problem, it is possible to indicate an addition of $2 \mathrm{mg} \cdot \mathrm{L}^{-1}$ of silver nitrate in culture media, for the micropropagation of passion fruit plant, allowing the controlling of the atmosphere inside the culture test tubes, during the establishment of explants and other steps of the process.
\end{abstract}




\section{Keywords}

Passion Fruits, Tropical Fruits, Plant Propagation, Reduced Growth, Ethylene

\section{Introduction}

The genus Passiflora includes over 600 species, it is widely distributed throughout the Americas and has high genetic variability to be exploited in breeding programs [1] [2]. The species Passiflora edulis Sims (yellow passion fruit) and Passiflora alata Curtis (sweet passion fruit) are the most cultivated worldwide, being the yellow passion fruit the most cultivated in Brazil, representing 95\% of the crop area [3] [4]. Due to its high susceptibility to disease, it is necessary to constantly change the cultivated area, to avoid a high number of diseases to accumulate in the traditional growing regions, thus decreasing the intensity of damages. The use of resistant rootstock varieties or hybrids could minimize the risk for the crop and consequently improve the expansion [5].

The species Passiflora gibertii N. E. Br., presents resistance to premature death, cladosporiose, bacterial blight and anthracnose, which makes it a strong candidate to be use as rootstock and also in breeding programs [6]. The tissue culture techniques can provide a wide plant availability of good genetic and phytosanitary quality. Among these techniques, the in vitro cloning of plants, known as micropropagation, is the fastest way to multiply a particular plant or genotype, which presents desirable agronomic characteristics.

This technique has been used by several authors and most of the publications focus on Passiflora edulis f. edulis (purple passion fruit), Passiflora edulis f. flavicarpa (yellow passion fruit) and Passiflora alata (sweet passion fruit) [7]-[19].

The need for repeated subcultures, the requirement of infrastructure and labor-specialized work and the frequent phytosanitary contamination, have been hindering the in vitro cultivation [18].

For the success of this technique, some factors should be considered, such as the explant type, genotype, nutrient media and the environmental conditions to maintain the culture. In general, nodal segments and steam apices are the most widely used type of explant micropropagation for passion fruit.

According to [20], most of the authors utilize MS media for most of the studied species of Passiflora, in its integral form, or containing half of its components. However, passion fruit plants are capable of producing high rates of ethylene, a gaseous regulator, which may cause many problems in micropropagation of their species, once the production of this phytohormone in excess may induce a buildup in culture flasks, hindering the development of explants and the morphogenesis in vitro.

The ethylene accumulation has an adverse effect on plant development, affecting differentiation, development, morphology and plant growth, reducing foliar expansion and shoots length, inhibiting the regeneration of new shoots 
and causing apical necrosis, besides promoting foliar abscission in in vitro cultures [21] [22] [23].

There are available in the literature reports of several cultures that are influenced by the presence of ethylene in in vitro cultivation. The decrease in the rate of regeneration has been observed in chili pepper, orange and potato [24] [25] [26]. For tomato, on the other hand, [27] verified an increase in regeneration rates.

Several studies have been conducted aiming at decreasing the rate of ethylene in culture flasks, being, the addition of "ethylene inhibitors compounds", such as silver nitrate, cobalt chloride and silver thiosulfate considered as possible alternatives [9] [12] [14] [23] [26] [28].

This work aimed at evaluating the effect of silver nitrate as an inhibitor of ethylene action in the in vitro development and conservation of passion fruit.

\section{Material and Methods}

Experiments were conducted in the Laboratory of Culture and Tissues, in the National Cassava and Fruits Research Center (EMBRAPA, Cruz das Almas, Bahia, Brazil), using the accesses characterized by Passiflora gibertii N. E. Br., from the Active Germplasm Bank of Passion Fruit from the same institution.

In the vegetation house, seeds from controlled pollination were sown in polyethylene plastic bags of $10 \times 25 \mathrm{~cm}$, using a mixture of soil and cattle manure, in a proportion of 3:1, considering the necessary phytosanitary care with the seed quality, preparation of substratum, sowing and conduction of seedlings.

Microcuttings of $P$. gibertii, with $1 \mathrm{~cm}$ length, were collected from the vegetation house, and cultivated in test tube of $20 \times 150 \mathrm{~mm}$, in $20 \mathrm{~mL}$ MS medium [21], supplemented with $30 \mathrm{~g} \cdot \mathrm{L}^{-1}$ of saccharose, $2 \mathrm{~g} \cdot \mathrm{L}^{-1}$ of Phytagel $^{\circledast}$ and silver nitrate in concentrations of $0,1,2,4$ and $8 \mathrm{mg} \cdot \mathrm{L}^{-1}$, with $\mathrm{pH}$ adjusted to 5.8 and autoclaved at $121^{\circ} \mathrm{C}\left(1 \mathrm{~kg} \cdot \mathrm{m}^{-2}\right)$ per 20 minutes. The cultivation was performed in photoperiod of 16 hours, $27^{\circ} \mathrm{C} \pm 1^{\circ} \mathrm{C}$ temperature and flow photons density of $22 \mu \mathrm{E} \mathrm{m}^{-2} \cdot \mathrm{s}^{-1}$.

A completely randomized design was used with 30 replications per treatment. The experimental plot was represented by a test tube containing one explant. Evaluations were performed at 30,60 and 90 days after incubation of explants in culture media without subculture. We evaluated: 1$)$ shoots length $(\mathrm{cm})$ : considered shoots above $1 \mathrm{~cm} ; 2)$ roots number: considered developed roots; 3 ) leaves number: Considered fully expanded leaves and 4) coloring of leaves: The following rating scale was assigned: 1-totally green leaves, 2-light green leaves and 3-yellowish leaves (early senescence). Data were subjected to analysis of variance considering a completely randomized statistical model in a split-plot design subdivided in time. The averages obtained were submitted to the Dunnet test at a $5 \%$ probability, using SAS ${ }^{\oplus}$ and to analysis regression using SISVAR $5.6^{\circledR}$ [29]. Polynomial regression equations were adjusted to analyses of variance, in order to compare the average of treatments [30]. 


\section{Results and Discussion}

The results revealed considerable variation in the shoots length, roots number, as well as the number and color of leaves. Statistically significant differences ( $\mathrm{p} \leq$ 0.01 ) were observed among the treatments for all sources of analyzed variation. The variables shoots length and leaves color showed the lowest coefficient of variation, $2 \%$ and $7 \%$, respectively, while the variables leaves number and roots number presented the highest values of $18 \%$ and $25 \%$, respectively (Table 1 ).

Table 2 presents the difference between the means of treatments with $\mathrm{AgNO}_{3}$ (silver nitrate) and the control group for the variables length of shoot, number of leaves, number of roots and color of leaves, and its significance according to Dunnett's test, with $5 \%$ probability. The addition of silver nitrate in the development of the passion fruit explants promoted satisfactory results when compared to the control treatment. However, for some variables, the addition of this substance was significant up to a certain concentration, since from this point the results did not differ statistically from the control.

In general, for all variables, the control was lower than the treatments containing silver nitrate as an inhibitor of ethylene action. Concerning the variable length of shoot, at 30 days of evaluation, there was a significant difference and superiority of silver nitrate treatments 1 and 2 compared to control. For the assessment at 60 and 90 days, only concentration of $1 \mathrm{mg} \cdot \mathrm{L}^{-1} \mathrm{AgNO}_{3}$ were statistically significant higher than the control $(\mathrm{P}<0.05)$ (Table 2$)$.

The addition of silver nitrate favored the increase in the number of leaves in all evaluation periods compared to its absence in the culture media. Lower scores were recorded at 30 and 60 days of evaluation, with concentrations of $\mathrm{AgNO}_{3}$ at 2 and $4 \mathrm{mg} \cdot \mathrm{L}^{-1}$. After 90 days, only concentration of $1 \mathrm{mg} \cdot \mathrm{L}^{-1}$ of silver nitrate did not differ statistically from the control. The other concentrations promoted a decrease in the scores and, consequently, major vigor (Table 2).

After 30 days of evaluation, there was a significant increase in the number of roots, utilizing only $2 \mathrm{mg} \cdot \mathrm{L}^{-1}$ of silver nitrate. For the evaluation periods of 60

Table 1. Analysis of variance for the variables shoots length (SL), leaves number (LN), roots number (RN) and leaves coloration (LC).

\begin{tabular}{|c|c|c|c|c|c|}
\hline \multirow{2}{*}{ Sources of variation } & \multirow{2}{*}{$\mathrm{DF}^{*}$} & \multicolumn{4}{|c|}{ Mean Squares } \\
\hline & & $\mathrm{SL}(\mathrm{cm})^{1}$ & $\mathrm{LN}^{2}$ & $\mathrm{RN}^{2}$ & $\mathrm{LC}^{2}$ \\
\hline Treatment & 4 & $0.7732^{* *}$ & $64.8997^{* *}$ & $2.3843^{* *}$ & $0.5549^{* *}$ \\
\hline Evaluation & 2 & $0.2512^{* *}$ & $15.5325^{* *}$ & $0.5235^{* *}$ & $0.0123^{\text {ns }}$ \\
\hline Treatment $\mathrm{x}$ Evaluation & 8 & $0.0937^{* *}$ & $1.4373^{* *}$ & $0.1377^{* *}$ & $0.0095^{\mathrm{ns}}$ \\
\hline Coefficient of variation (\%) & & 2.00 & 18.00 & 25.00 & 7.00 \\
\hline Overall Average & & 2.1592 & 5.6059 & 0.3423 & 1.3374 \\
\hline
\end{tabular}

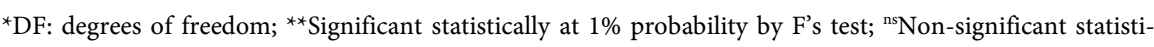
cally. ${ }^{1}$ Transformed to $\ln (x+10) ;{ }^{2}$ Transformed to $\sqrt{(x+0.5)}$. 
Table 2. Dunnet test for the variables shoots length, leaves number, roots number and leaves coloration evaluated at 30,60 and 90 days after inoculation.

\begin{tabular}{|c|c|c|c|}
\hline \multirow{3}{*}{ Treatments } & \multicolumn{3}{|c|}{ Evaluation (Days) } \\
\hline & 30 & 60 & 90 \\
\hline & \multicolumn{3}{|c|}{ Shoots length $(\mathrm{cm})$} \\
\hline Control & 1.14 & 1.34 & 1.72 \\
\hline 1 & $2.27^{* *}$ & $4.44^{* *}$ & $6.78^{* *}$ \\
\hline 2 & $1.71^{* *}$ & $2.09^{\text {ns }}$ & $2.51^{\mathrm{ns}}$ \\
\hline 4 & $1.24^{\mathrm{ns}}$ & $1.36^{\mathrm{ns}}$ & $1.43^{\text {ns }}$ \\
\hline \multirow[t]{2}{*}{8} & $1.32^{\mathrm{ns}}$ & $1.44^{\mathrm{ns}}$ & $1.53^{\text {ns }}$ \\
\hline & \multicolumn{3}{|c|}{ Leaves number } \\
\hline Control & 0.47 & 0.90 & 1.20 \\
\hline 1 & $6.00^{* *}$ & $9.50^{* *}$ & $13.73^{* *}$ \\
\hline 2 & $5.79^{* *}$ & $9.90^{* *}$ & $10.83^{* *}$ \\
\hline 4 & $2.23^{* *}$ & $4.97^{* *}$ & $4.97^{* *}$ \\
\hline \multirow[t]{2}{*}{8} & $2.93^{* *}$ & $5.52^{* *}$ & $5.38^{* *}$ \\
\hline & \multicolumn{3}{|c|}{ Roots number } \\
\hline Control & 0.00 & 0.00 & 0.17 \\
\hline 1 & $0.23^{\mathrm{ns}}$ & $0.83^{* *}$ & $1.10^{* *}$ \\
\hline 2 & $0.45^{* *}$ & $1.00^{* *}$ & $1.34^{* *}$ \\
\hline 4 & $0.00^{\mathrm{ns}}$ & $0.00^{\mathrm{ns}}$ & $0.00^{\mathrm{ns}}$ \\
\hline \multirow[t]{2}{*}{8} & $0.00^{\mathrm{ns}}$ & $0.00^{\mathrm{ns}}$ & $0.03^{\text {ns }}$ \\
\hline & \multicolumn{3}{|c|}{ Leaves coloration } \\
\hline Controle & 1.67 & 1.67 & 1.86 \\
\hline 1 & $1.45^{\mathrm{ns}}$ & $1.69^{\mathrm{ns}}$ & $1.67^{\mathrm{ns}}$ \\
\hline 2 & $1.14^{* *}$ & $1.14^{* *}$ & $1.14^{* *}$ \\
\hline 4 & $1.09^{* *}$ & $1.13^{* *}$ & $1.17^{* *}$ \\
\hline 8 & $1.43^{\mathrm{ns}}$ & $1.33^{\mathrm{ns}}$ & $1.27^{* *}$ \\
\hline
\end{tabular}

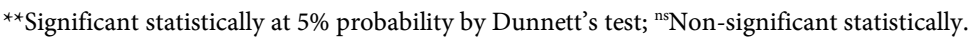

and 90 days, 1 and $2 \mathrm{mg} \cdot \mathrm{L}^{-1}$ of silver nitrate showed higher and significant values when compared to the control (Table 2).

In the evaluations of 30 and 60 days the use of 2 and $4 \mathrm{mg} \cdot \mathrm{L}^{-1}$ of $\mathrm{AgNO}_{3}$ affected the color of the leaves, reducing the values obtained for this variable and differing from the control treatment. At 90 days the highest concentrations $(2,4$ and $\left.8 \mathrm{mg} \cdot \mathrm{L}^{-1}\right)$ also decreased the means of leaves colorations, differing from the control (Table 2).

Figure 1 presents the responses of four variables to several concentrations of silver nitrate. Regarding the shoot length, it is possible to observe a different behavior between treatments. Treatment with $1 \mathrm{mg} \cdot \mathrm{L}^{-1}$ silver nitrate promoted 

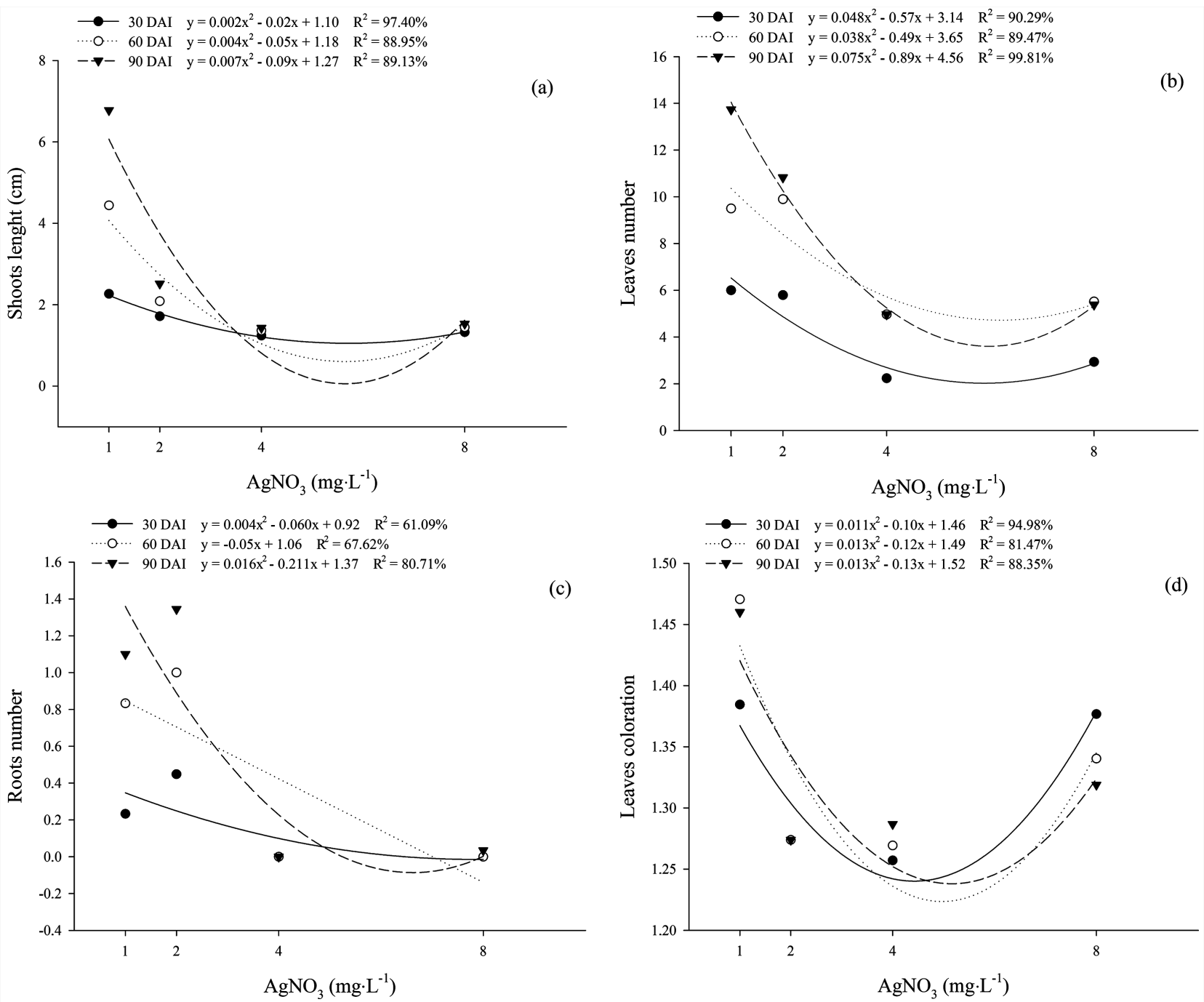

Figure 1. Silver nitrate concentration related to the periods of evaluation for the variables: shoots length (a); leaves number (b); roots number (c); and leaves coloration (d).

higher growth of shoots when compared to the other concentrations in all evaluation periods (Figure 1(a)).

By mean values of number of leaves, depending on the treatments and evaluation (Figure $1(\mathrm{~b})$ ), it was possible to verified that treatments with 1 and $2 \mathrm{mg} \cdot \mathrm{L}^{-1}$ of silver nitrate presented a higher increase in the number of leaves, and the treatment with $1 \mathrm{mg} \cdot \mathrm{L}^{-1}$ of $\mathrm{AgNO}_{3}$, at 90 days, presented a higher number of leaves than the others. A better development of the radicular system was verified in the treatment containing $2 \mathrm{mg} \cdot \mathrm{L}^{-1}$ of silver nitrate, following by a treatment containing $1 \mathrm{mg} \cdot \mathrm{L}^{-1} \mathrm{AgNO}_{3}$. The treatment of $4 \mathrm{mg} \cdot \mathrm{L}^{-1}$ silver nitrate did not present development of radicular system, and the treatments with $8 \mathrm{mg} \cdot \mathrm{L}^{-1}$ of $\mathrm{AgNO}_{3}$ presented very few roots at 90 days of evaluation (Figure $1(\mathrm{c})$ ). In Figure $1(\mathrm{~d})$, it is possible to observe that the treatments presenting more intense coloration, with values near to 1 , were found in treatments with 2 and $4 \mathrm{mg} \cdot \mathrm{L}^{-1}$ of silver nitrate. 
The results recorded in this investigation revealed considerable variation in the length of shoots, number of roots, as well as the number and color of leaves, in microplants cultivated with silver nitrate, when compared to those cultivated without this compound. The results confirm previous findings on the inhibitory effect of ethylene on in vitro morphogenesis of passion fruit. Assuming that the rate of accumulation of ethylene in the test tubes is relatively low but still enough to cause an inhibitory effect, it is possible to affirm that there is a high sensitivity of passion fruit tissue to ethylene.

Overall, for all variables, the control was lower than the treatments containing silver nitrate as an inhibitor of ethylene action (Figure 2(a)). In order to minimize the effect of the accumulation of ethylene, in the development of passion fruit shoots, [8] added silver nitrate to the culture media supplemented with benzyladenine (BAP) or thidiazuron (TDZ) and verified that adventitious buds developed in culture media with supplemented $\mathrm{AgNO}_{3}$ were more vigorous.

For adventitious bud induction, [3] affirms that tissue culture medium supplemented with silver nitrate and explants incubation under a 16 hours photoperiod was crucial.

Reference [9] utilized, as ethylene inhibitor, $1 / 4$ of silver nitrate in sodium thiosulfate solution, forming silver thiosulfate (STS), and verified that the addition of STS showed to be efficient in the inhibition of the action of ethylene without reflecting in the organogenesis responses.

In our investigation, we observed that, regarding the variable length of shoot, significant differences and superiorities of treatments up to $2 \mathrm{mg} \cdot \mathrm{L}^{-1}$ of silver nitrate (Figure 2(c)) were recorded when compared to the control. Moreover, silver nitrate favored the increasing in the number of leaves in all evaluation periods compared to its absence in the culture media. This corroborates results was observed that the inhibition of ethylene synthesis and its action lead to an increase in the number of developed axillary buds and in the mean area of leaves per explant [23].

Related to the coloration of leaves, considering that lower scores would reflect in green leaves with more intense coloration, the recommended treatments would be concentrations of 2 (Figure $2(\mathrm{c})$ ) and $4 \mathrm{mg} \cdot \mathrm{L}^{-1}$ of silver nitrate (Figure $2(d))$, warranting a major vigor to the plant.

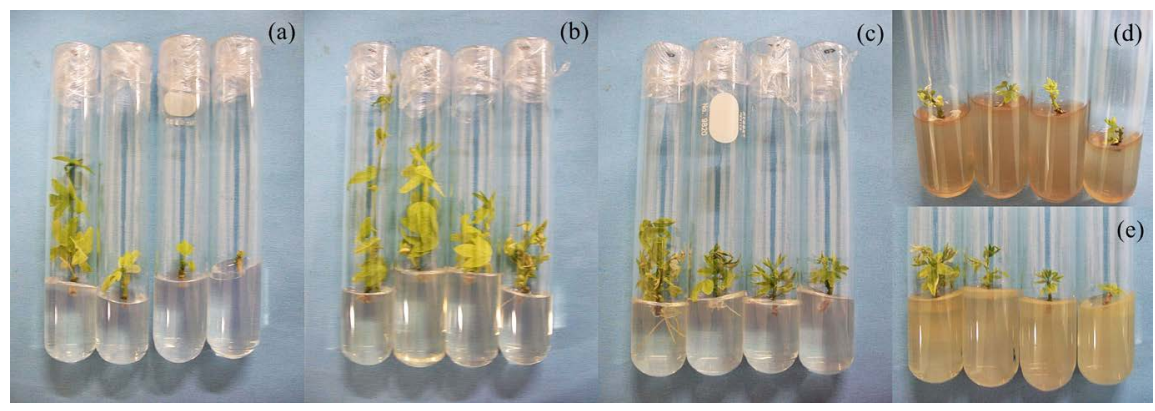

Figure 2. Microplants of passion fruit cultivated in control treatment (with no $\mathrm{AgNO}_{3}$ ) (a) and with 1 (b), 2 (c), 4 (d) and $8 \mathrm{mg} \cdot \mathrm{L}^{-1}$ (e) of $\mathrm{AgNO}_{3}$ at 90 days after inoculation. 
The quality of microplants is defined by the number of leaves expanded throughout the period of cultivation, as well as by coloration. In this study, when considering the growth of sproots and number of leaves, the treatments with 1 (Figure 2(b)) and $2 \mathrm{mg} \cdot \mathrm{L}^{-1}$ (Figure 2(c)) presented the most satisfactory results. When considering coloration of leaves, treatments with 2 and $4 \mathrm{mg} \cdot \mathrm{L}^{-1}$ (Figure 2(d)) of silver nitrate presented better results.

The addition of silver nitrate was also positive to the increase in the number of roots of the microplants, especially for doses of $2 \mathrm{mg} \cdot \mathrm{L}^{-1}$. Obtaining microplants with a well-developed root system is of great importance for their survival and growth, particularly related to the acclimatization and transplantation to the field.

Reference [31] studied the effects of ethylene in the in vitro morphogenesis of passion fruit plant, and according to them, the ethylene inhibitor used, silver thiosulfate - STS, significantly increased the frequency of buds of foliar explants, promoting a delay in the senescence of leaves. However, these authors did not quantify the effect of ethylene in the degradation of pigmentation. Once the passion fruit is a climacteric species, the inhibition of ethylene action probably benefits morphogenesis to provide an increase in the growth of leaves and consequently a greater number of axillary buds.

Similar results were obtained by [32], which added silver nitrate to the culture media, and managed to revert the low percentage of regeneration, achieving the inhibition of foliar senescence and, consequently, the abscission of the petiole. Reference [33] tested the effects of 1-aminocyclopropane-1-carboxylic acid (ACC), the precursor of ethylene, as well as the effects of silver thiosulfate (STS) and aminoethoxyvinylglycine (AVG), inhibitors compounds of this phytohormone, and proved that ethylene strongly affected the development of axillary bud of passion fruit, leading to an intense senescence and consequent death of branches. Similar results were reported in an in vitro experiment, aiming the development of passion fruit roots [31].

Reference [8] verified that the organogenesis is optimized with the use of silver nitrate, presenting more vigorous adventitious buds and higher number of buds per explant. It was observed that direct organogenesis occurred more efficiently when explants of $P$. alata were cultured in media supplemented with silver nitrate and cytokinins, recommended the supplementation for the formation of plants buds [34].

The in vitro growth rate of cassava confirmed the efficiency of silver nitrate as an ethylene inhibitor [35]. These authors used $5 \mathrm{mg} \cdot \mathrm{L}^{-1}$ of silver nitrate in culture media, and manage to reduce the growth rate of plants, increasing the period of subculture in more than six months. Before, in an investigation with wheat, verified that the addition of the same $5 \mathrm{mg} \cdot \mathrm{L}^{-1}$ silver nitrate significantly increased the percentage of anther response rate in the formation of somatic embryos [36].

In in vitro potato culture, verified that in the system sealed with silver nitrate, 
there was an increase of five folds related to the foliar area, six folds related to the fresh weight of leaves and a significant increase in the size of roots [37].

These results corroborate that silver nitrate has beneficial effects on regeneration and clonal propagation of several economically important plants [38].

The species Passiflora presents some problems related to the development of an efficient protocol for micropropagation, and the action of ethylene may be one of the factors associated to this limitation.

The obtained results support the assumption of high sensitivity of passion fruit tissues to ethylene, which reflects in the lost of vigor and in the induction of culture senescence by its accumulation.

This work can surely be an excellent reference for future experiments, and may contribute significantly to the study of tissue culture and consequently to the maintenance of in vitro germplasm banks of passion fruit.

\section{Conclusion}

Based on obtained results, and in order to mitigate this problem, it is possible to indicate an addition of $2 \mathrm{mg} \cdot \mathrm{L}^{-1}$ of silver nitrate in culture media, for the micropropagation of passion fruit plant, allowing the controlling of the atmosphere inside the culture test tubes, during the establishment of explants and other steps of the process.

\section{Acknowledgements}

The authors thank FAPESP for the funding of the project that allowed the creation of the Laboratory of Applied Statistics (LEA) (Process: 2015/18225-4) responsible for the statistical analyzes performed in this work.

\section{References}

[1] Rosa, Y.B.C.J., Aizza, L.C.B., Bello, C.C.M. and Dornelas, M.C. (2014) PmTCP1 Encodes a Putative TCP Transcription Factor and Is Differentially Expressed during In Vitro Organogenesis in Passiflora. In Vitro Cellular \& Developmental Biology Plant, 50, 36-44. https://doi.org/10.1007/s11627-013-9585-x

[2] Reis, R.V., Oliveira, E.J., Viana, A.P., Pereira, T.N.S., Pereira, M.G. and Morais-Silva, M.G. (2011) Genetic Diversity in Recurrent Selection of Yellow Passion Fruit Detected by Microsatellites Markers. Pesquisa Agropecuária Brasileira, 46, 51-57. https://doi.org/10.1590/S0100-204X2011000100007

[3] Vieira, L.M., Rocha, D.I., Taquetti, M.F., Silva, L.C., Campos, J.M.S., Viccini, L.F. and Otoni, W.C. (2014) In Vitro Plant Regeneration of Passiflora setacea D.C. (Passifloraceae): The Influence of Explant Type, Growth Regulators, and Incubation Conditions. In Vitro Cellular \& Developmental Biology - Plant, 50, 738-745. https://doi.org/10.1007/s11627-014-9650-0

[4] Santos, C.L., Viana, A.P., Freitas, M.S.M., Carvalho, A.J.C. and Rodrigues, D.L. (2017) Relationship between Yield and Fruit Quality of Passion Fruit $\mathrm{C}_{03}$ Progenies under Different Nutritional Levels. Revista Brasileira de Fruticultura, 39. https://doi.org/10.1590/0100-29452017691

[5] Meletti, L.M.M. (2011) Avanços na cultura do maracujá no Brasil. Revista Brasileira 
de Fruticultura, 33, 83-91. https://doi.org/10.1590/S0100-29452011000500012

[6] Junqueira, N.T.V., Braga, M.F., Faleiro, F.G., Peixoto, J.R. and Bernacci, L.C. (2005) Potencial de espécies silvestres de maracujazeiro como fonte de resistência a doenças. In: Faleiro, F.G., Junqueira, N.T.V. and Braga, M.F., Eds., Maracujá: Germoplasma e melhoramento genetic, Embrapa Cerrados, Planaltina DF, 81-106.

[7] Isutsa, D.K. (2004) Rapid Micropropagation of Passion Fruit (Passiflora edulis Sims) Varieties. Scientia Horticulturae, 99, 395-400.

[8] Trevisan, F. and Mendes, B.M.J. (2005) Optimization of Passionfruit (Passiflora edulis f. flavicarpa) in Vitro Organogenesis. Scientia Agricola, 62, 346-350. https://doi.org/10.1590/S0103-90162005000400007

[9] Trevisan, F. and Mendes, B.M.J. (2006) Resistance to Passion Fruit Woodiness Virus in Transgenic Passionflower Expressing the Virus Coat Protein Gene. Plant Diseases, 90, 1026-1030. https://doi.org/10.1094/PD-90-1026

[10] Figueiredo, M.A., Paiva, R., Souza, A.C., Porto, J.M.P., Nogueira, G.F. and Soares F.P. (2007) In Vitro Induction of Callus in Two Species of Native Passion Fruit Plants. Revista Brasileira de Biociência, 5, 288-290.

[11] Dias, L.L.C., Santa-Catarina, C., Ribeiro, D.M., Barros, R.S., Floh, E.I.S. and Otoni, W.C. (2009) Ethylene and Polyamine Production Patterns during in Vitro Shoot Organogenesis of Two Passion Fruit Species as Affected by Polyamines and Their Inhibitor. Plant Cell, Tissue and Organ Culture, 99, 199-208.

https://doi.org/10.1007/s11240-009-9594-y

[12] Dias, L.L.C., Ribeiro, D.M., Santa-Catarina, C., Barros, R.S., Floh, E.I.S. and Otoni, W.C. (2010) Ethylene and Polyamine Interactions in Morphogenesis of Passiflora cincinnata: Effects of Ethylene Biosynthesis and Action Modulators, as well as Ethylene Scavengers. Plant Growth Regulation, 62, 9-19. https://doi.org/10.1007/s10725-010-9478-5

[13] Santos, F.C., Ramos, J.D., Pasqual, M., Rezende, J., Santos, F.C. and Villa, F. (2010) Micropropagation of Passion Fruit Sleep. Revista Ceres, 57, 112-117. https://doi.org/10.1590/S0034-737X2010000100018

[14] Monteiro-Hara, A.C.B.A., Jadão, A.S., Mendes, B.M.J., Rezende, J.A.M., Trevisan, F., Mello, A.P.O.A., Vieira, M.L.C., Meletti, L.M.M. and Piedade, S.M.S. (2011) Genetic Transformation of Passionflower and Evaluation of R1 and R2 Generations for Resistance to Cowpea aphid Borne Mosaic Virus. Plant Disease, 95, 1021-1025. https://doi.org/10.1094/PDIS-12-10-0873

[15] Garcia, R., Pacheco, G., Falcão, E., Borges, G. and Mansur, E. (2011) Influence of Type of Explant, Plant Growth Regulators, Salt Composition of Basal Medium, and Light on Callogenesis and Regeneration in Passiflora suberosa L. (Passifloraceae). Plant Cell, Tissue and Organ Culture, 106, 47-54. https://doi.org/10.1007/s11240-010-9892-4

[16] Pacheco, G., Garcia, R., Lugato, D., Vianna, M. and Mansur, E. (2012) Plant Regeneration, Callus Induction and Establishment of Cell Suspension Cultures of Passiflora alata Curtis. Scientia Horticulturae, 144, 42-47.

[17] Soares, W., Rêgo, M., Rêgo, E., Barroso, P., Nascimento, K. and Ferreira, K. (2012) In Vitro Establishment and Micropropagation of Passiflora foetida L. Revista Brasileira de Plantas Medicinais, 14, 138-142. https://doi.org/10.1590/S1516-05722012000500002

[18] Figueiredo-Carvalho, M.A., Paiva, R., Vargas, D.P., Porto, J.M.P., Herrera, R.C. and Stein, V.C. (2012) In Vitro Germination of Passiflora gibertii N. E. Brown with Mechanical Scarification and Gibberellic Acid. Semina: Ciências Agrárias, 33, 
1027-1032. https://doi.org/10.5433/1679-0359.2012v33n3p1027

[19] Lugato, D., Simão, M.J., Garcia, R., Mansur, E. and Pacheco, G. (2014) Determination of Antioxidant Activity and Phenolic Content of Extracts from in Vivo Plants and in Vitro Materials of Passiflora alata Curtis. Plant Cell, Tissue and Organ Culture, 118, 339-346. https://doi.org/10.1007/s11240-014-0486-4

[20] Passos, I.R.S. and Bernarcci, L.C. (2005) Tissue Culture Applied to the Maintenance of in Vitro Germplasm and Breeding of Passion Fruit (Passiflora spp.). In: Faleiro, F.G., Junqueira, N.T.V. and Braga, M.F., Eds., Passionflower. Germplasm and Breeding, Planaltina DF, 361-384.

[21] Murashige, T. and Skoog, F. (1962) A Revised Medium for Rapid Growth and Bioassays with Tobacco Tissue Culture. Physiologia Plantarum, 15, 437-497. https://doi.org/10.1111/j.1399-3054.1962.tb08052.x

[22] Erig, A.C. and Schuch, M.W. (2005) In Vitro Establishment of Blueberry Trees Starting from Nodal Segments. Scientia Agrária, 6, 91-96. https://doi.org/10.5380/rsa.v6i1.4603

[23] Nepomuceno, C.F., Rios, A.P.D.S., Queiroz, S.R.O.D., Pelacani, C.R. and Santana, J.R.F.D. (2007) Control of Leaf Abscission and in Vitro Morphogenesis in Cultures of Anadenanthera colubrina (Vell.) Brenan var. Cebil Altschul. Revista Árvore, 31, 967-975. https://doi.org/10.1590/S0100-67622007000500021

[24] Batista, D.S., Dias, L.L.C., Macedo, A.F., Rêgo, M.M., Rêgo, E.R., Floh, E.I.S. and Otoni, W.C. (2013) Suppression of Ethylene Levels Promotes Morphogenesis in Pepper (Capsicum annuum L.). In Vitro Cellular \& Developmental Biology Plant, 49, 759-764. https://doi.org/10.1007/s11627-013-9559-Z

[25] Mendes, A.F.S., Cidade, L.C., Otoni, W.C., Soares-Filho, W.S. and Costa, M.G.C. (2011) Role of Auxins, Polyamines and Ethylene in Root Formation and Growth in Sweet Orange. Biologia Plantarum, 55, 375-378. https://doi.org/10.1007/s10535-011-0058-y

[26] Gong, Y., Gao, F. and Tang, K. (2005) In Vitro High Frequency Direct Root and Shoot Regeneration in Sweet Potato using the Ethylene Inhibitor Silver Nitrate. South African Journal of Botany, 71, 110-113.

[27] Trujillo-Moya, C. and Gisbert, C. (2012) The Influence of Ethylene and Ethylene Modulators on Shoot Organogenesis in Tomato. Plant Cell, Tissue and Organ Culture, 111, 41-48. https://doi.org/10.1007/s11240-012-0168-Z

[28] Kokina, I., Gerbreders, V., Sledevskis, E. and Bulanovs, A. (2013) Penetration of Nanoparticles in Flax (Linum usitatissimum L.) Calli and Regenerants. Journal of Biotechnology, 165, 127-132.

[29] Ferreira, D.F. (2011) Sisvar: A Computer Statistical Analysis System. Ciência e Agrotecnologia, 35, 1039-1042. https://doi.org/10.1590/S1413-70542011000600001

[30] Pimentel-Gomes, F. (2009) Course in Experimental Statistics. 15th Edition, FEALQ, Piracicaba SP, 451.

[31] Barbosa, W.M., Otoni, W.C., Carnelossi, M., Silva, E., Azevedo, A.A. and Vieira, G. (2001) Rhizogenesis in Vitro Shoot Cultures of Passion Fruit (Passiflora edulisf. flavicarpa Deg.) Is Affect by Ethylene Precursor and by Inhibitors. International Journal of Horticultural Science, 7, 47-51.

[32] Purnhauser, L., Medgyesy, P., Czako, M., Dix, P.J. and Marton, L. (1987) Stimulation of Shoot Regeneration in Triticum aestivum and Nicotiana plumbaginifolia Viv. Tissue Cultures using the Ethylene Inhibitor $\mathrm{AgNO}_{3}$. Plant Cell Reports, 6, 1-4. https://doi.org/10.1007/BF00269725 
[33] Reis, L.B., Paiva-Neto, V.B., Toledo-Picoli, E.A., Finger, L.F. and Otoni, W.C. (2003) Axillary Bud Development of Passion Fruit as Affected by Ethylene Precursor and Inhibitors. In Vitro Cellular \& Developmental Biology Plant, 39, 618-622. https://doi.org/10.1079/IVP2003455

[34] Pinto, A.P.C., Monteiro-Hara, A.C.A., Stipp, L.C.L. and Mendes, B.M.J. (2010) In Vitro Organogenesis of Passiflora alata. In Vitro Cellular \& Developmental Biology Plant, 46, 28-33. https://doi.org/10.1007/s11627-009-9251-5

[35] Mafla, G., Roa, J.C. and Guevara, C.L. (2000) Advances on the in Vitro Growth Control of Cassava, using Silver Nitrate. In: Carvalho, L.J.C.B., Thro, A.M. and Vilarinhos, A.D., Eds., International Scientific Meeting Cassava Biotechnology, 4, Salvador BA, Embrapa-Cenargen, Brasília DF, 439-446.

[36] Ghaemi, M., Sarrafi, A. and Alibert, G. (1994) The Effects of Silver Nitrate, Colchicine, Cupric Sulfate and Genotype on the Production of Embryoids from Anthers of Tetraploid Wheat (Triticum turgidum). Plant Cell, Tissue and Organ Culture, 36, 355-359. https://doi.org/10.1007/BF00046093

[37] Zobayed, S.M.A., Armstrong, J. and Armstrong, W. (2001) Micropropagation of Potato: Evaluation of Closed, Diffusive and Forced Ventilation on Growth and Tuberization. Annals of Botany, 87, 53-59. https://doi.org/10.1006/anbo.2000.1299

[38] Kumar, V., Parvatam, G. and Ravishankar, G.A. (2009) AgNO3-A Potential Regulator of Ethylene Activity and Plant Growth Modulator. Electronic Journal of Biotechnology, 12. https://doi.org/10.2225/vol12-issue2-fulltext-1 